\title{
Serological survey of lyssaviruses in synanthropic bats and human exposure to bats in Slovakia
}

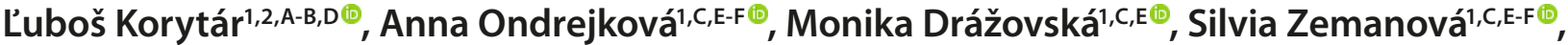 \\ Marián Prokeš ${ }^{1, A-B, D \odot}$ \\ 1 University of Veterinary Medicine and Pharmacy in Košice, Slovak Republic \\ 2 Slovak Bat Conservation Society, Bardejov, Slovak Republic \\ A - Research concept and design, B - Collection and/or assembly of data, C - Data analysis and interpretation, \\ $D$ - Writing the article, E - Critical revision of the article, F - Final approval of the article
}

Korytár L', Ondrejková A, Drážovská M, Zemanová S, Prokeš M. Serological survey of lyssaviruses in synanthropic bats and human exposure to bats in Slovakia. Ann Agric Environ Med. 2022; 29(1): 44-49. doi: 10.26444/aaem/146208

\begin{abstract}
Introduction. Bats are considered natural reservoirs for lyssaviruses. A total of 17 out of 19 known lyssaviruses circulate in bat populations. Lyssaviruses cause rabies in animals and humans. The transmission of lyssaviruses from European bats to terrestrial animals and humans is rare, but the risk of infection still exists even in developed countries. Slovakia is currently a rabies-free country.

Objective. The aim of the study was to assess the potential circulation of EBLV-1 in synanthropic bats present in human inhabited buildings, and to give an overview of human exposure to bats.

Materials and method. A passive serological survey targeted the prevalence of antibodies to bat lyssaviruses in synanthropic bats between 2009 - 2019. A total of 598 bats of the species Pipistrellus pipistrellus, Pipistrellus pygmaeus, Eptesicus serotinus, Nyctalus noctula and Vespertilio murinus were captured in buildings mainly in Eastern Slovakia, and examined by the rapid fluorescent focus inhibition test (RFFIT).

Results. Lyssavirus-specific antibodies were detected in 2 (0.3\%) of the 598 examined bats. Additionally, brain tissues of bats found dead were examined using the standard fluorescent antibody test (FAT) with negative results. An overview of available data on human exposure to bats recorded in Slovakia from 2007 - 2019 is also included.

Conclusions. The study confirmed the presence of lyssavirus antibodies in synanthropic bats in Slovakia, suggesting the active circulation of bat lyssaviruses in bat populations exploiting human buildings. Although the seroprevalence was found to be extremely low, the results show that any case of human exposure to bats must be treated with caution in order to protect public health.
\end{abstract}

\section{Key words}

seroprevalence, human exposure, surveillance, Slovakia, bats, lyssaviruses, One Health

\section{INTRODUCTION}

Bats play crucial ecosystem services as seed dispersers, pollinators, controllers of insects, and nutrient recyclers [1], but bats are also considered to be natural reservoirs of a wide range of microorganisms, especially viruses [2]. Close human-bat interactions, including the sharing the living spaces, may lead to the spill-over of zoonotic diseases into the human population [3].

The process of urbanization has had an impact on bats not only in the Central European region, but worldwide [4]. Bats use a variety of urban habitats throughout the year. Research indicates that different bat species vary in their response to urbanization [5]. Urbanization provides roosting opportunities and facilitates range expansion of particular Central European bat taxa [6,7]. Although the urban environment provides many benefits for bats, it can also expose them to new risks. Bats residing in buildings may be increasingly predated, for example, by birds of prey, such as the common kestrel (Falco tinnunculus), with which

Address for correspondence: Marián Prokeš, University of Veterinary Medicine and Pharmacy in Košice, Komenského 73, 04181 Košice, Slovak Republic E-mail: marian.prokes@uvlf.sk

Received: 30.12.2021; accepted: 28.01.2022; first published: 21.02.2022 they share the environment [8]. Bats in urban environments may also face the negative consequences of the renovation of buildings in which they have roosts [9].

Once an individual or a group of bats establish a roost in a building, other bats may recognize the newly established roosts by olfactory or acoustic cues. Consequently, members of a local bat population may begin exploiting the same roost [10]. The presence of bats in buildings may result in various problems; after gathering into large colonies, they may disturb the householders by loud noises, smell, excrement, etc. [11].

The occurrence of a total of 28 bat species has been confirmed in the Slovak Republic where they are common in various types of landscape, including urbanized areas [12]. Many bat species occurring in Slovakia can be defined as synanthropic due to the fact that they have a strong ecological association with humans $[13,14,15]$.

In Slovakia, the parti-coloured bat (Vespertilio murinus), the common noctule (Nyctalus noctula), the soprano bat (Pipistrellus pygmaeus) and the common pipistrelle (Pipistrellus pipistrellus) were documented as the most frequent bat species dwelling in blocks of flats and in prefabricated houses [16, 17].

Particular synanthropic bat species are known for their typical behavior called 'invasions', a phenomenon that occurs 
when large groups (tens to hundreds) of individuals invade human buildings where they frequently remain trapped [18]. In Slovakia, invasions are most often caused by the common pipistrelle (P. pipistrellus), but other species have also been described, such as the soprano pipistrelle (Pipistrellus pygmaeus), the Kuhl's pipistrelle (Pipistrellus kuhlii), and the common noctule (Nyctalus noctula) [16, 17].

Bats have been recognized as reservoir hosts of pathogenic microorganisms, among them a wide diversity of novel viruses [18, 19, 20]; thus, contact between bats and other animals and humans can be risky in certain circumstances [20].

The genus Lyssavirus includes the neurotropic viruses that cause rabies in animals and humans. From the global point of view, rabies poses one of the most important public health threats; nevertheless, rabies belongs to the neglected zoonotic diseases with the highest incidence among humans and susceptible animal species in Africa and Asia [21].

Bats are considered natural reservoirs for lyssaviruses [22] and a total of 17 out of 19 known lyssaviruses circulate in bat populations $[23,24,25]$. Insectivorous bats play an important role in the epidemiology of lyssaviruses [26]. Bats are the most prominent source of human rabies in the New World, Western Europe and Australia, especially where the disease in carnivores has been controlled [27].

The transmission of lyssaviruses from bats to terrestrial species and human is rare, but the risk of infection is still present, even in developed countries $[28,29,30]$.

According to the International Committee on Taxonomy of Viruses (ICTV, 2020), the genus Lyssavirus includes 17 classified viruses [23]. In Europe, six species of lyssaviruses circulate in bats: European bat lyssavirus 1 (EBLV-1), European bat lyssavirus 2 (EBLV-2), Bokeloh bat lyssavirus (BBLV), West Caucasian bat lyssavirus (WCBV), Lleida bat lyssavirus (LLEBV) and Kotalahti bat lyssavirus (KBLV) [31]. Retrospectively, $90 \%$ of the cases of bat rabies in Europe have been reported from serotine bats (E. serotinus) infected by EBLV-1 [32].

In Slovakia, two cases of EBLV-1 infection in bats have been recorded to-date. The EBLV-1 strain was isolated in 1991 from the brain of a common pipistrelle (P. pipistrellus) bat that injured a human in the Žiar nad Hronom district $[33,34]$. The second EBL-1 strain was isolated in 2000 from the serotine a bat (E. serotinus) that injured a human in the city of Prešov [33].

\section{OBJECTIVE}

The aim of this study was to assess the potential circulation of EBLV-1 in synanthropic bats present in human inhabited buildings in Slovakia from 2012 to 2019 based on serological screening and to give an overview of human exposure to bats during the investigational period.

\section{MATERIALS AND METHOD}

The capture of bats and collection of blood samples was authorized by the Ministry of Environment of the Slovak Republic based on official permits (No. 3501/2008-2.1/ jam; No. 5169/2012-2.2, No. 5376/2009-2.1/jan/2 and 3051/2019-6.3). All bats were handled in strict accordance with good animal practices [35]. The study was carried out between 2009 - 2019. The occurrence of bats inside the buildings examined was reported by householders and by condominium associations. Bats were captured directly inside buildings using a hand net and ultra-thin mist-nets (ECOTONE, Poland). After capture, bats were identified morphologically using an identification key [36]. Bats were sampled and released as soon as possible.

Blood samples (30-300 $\mu \mathrm{l}$, depending on the bat's size) were obtained by antebrachial vein ( $v v$. antebrachii) puncture using a micropipette and stored in an Eppendorf vials. Blood volume no higher than $0.1 \%$ of the body mass was collected from each bat. After collecting blood, pressure was applied on the puncture site to prevent bleeding. After processing, bats were placed in a $10 \%$ glucose solution. The vials with blood samples were stored at $4{ }^{\circ} \mathrm{C}$ until processing. The samples were then centrifuged for 10 minutes at $10,000 \mathrm{rpm}$. Sera were extracted using a micropipette and stored at $-80^{\circ} \mathrm{C}$ until analysis.

An adaptation of rapid fluorescent focus inhibition test (RFFIT) according Smith et al. (1973) [37] and Zalan et al. (1979) [38] in 96-well microtiter plates was used for the detection of specific antibodies in bat sera. Each sample was tested individually. Before testing, the sera were inactivated at $56^{\circ} \mathrm{C}$ for 30 minutes. The serum samples were serially diluted (1:27, 1:81, 1:243, 1:729) in BHK-21/C13 cell culture. Challenge rabies virus strain CVS11/Paris, adapted to replication on BHK-21/C13 cell culture, was used as challenge virus. The reference serum (OIE) was used as a control standard. The virus neutralizing antibodies (VNA) titres were calculated according to Reed and Muench (1938) [39].

In addition, brain tissues of 35 bats which were found freshly dead after trapping inside the buildings were examined by fluorescent antibody test, according Dean and Abelseth (1973) [40].

An overview of human exposure to bats was performed based on the annual reports of the Regional Public Health Authorities in the Slovak Republic from 2007 - 2019 [41-53].

\section{RESULTS}

Serological survey of synanthropic bats. In total, 598 bats were caught alive inside inhabited buildings between 2009 - 2019 (Tab. 1). The captured bats belonged to five species (E. serotinus, N. noctula, P. pipistrellus, P. pygmaeus and $V$. murinus). Bats have been found in buildings in the cities of Košice ( $n=503)$, Sabinov $(n=6)$, Bardejov $(n=28)$, Moldavanad- Bodvou $(n=12)$, Ružomberok $(n=48)$ and Jasov $(n=1)$ (Fig. 1). The majority of bats included in this study were captured between August and October, when bats move from maternity colony sites to transient fall sites. Several invasions of $P$. pipistrellus and $N$. noctula into residential areas of

Table 1. Bats tested serologically between 2009-2019

\begin{tabular}{lcccc}
\hline & Females & Males & Total & Positives \\
\hline E. serotinus & 2 & 1 & 3 & 0 \\
\hline N. noctula & 218 & 114 & 332 & 0 \\
\hline P. pipistrellus & 134 & 116 & 250 & 2 \\
\hline P. pygmaeus & 2 & 3 & 5 & 0 \\
\hline V. murinus & 0 & 8 & 8 & 0 \\
\hline
\end{tabular}




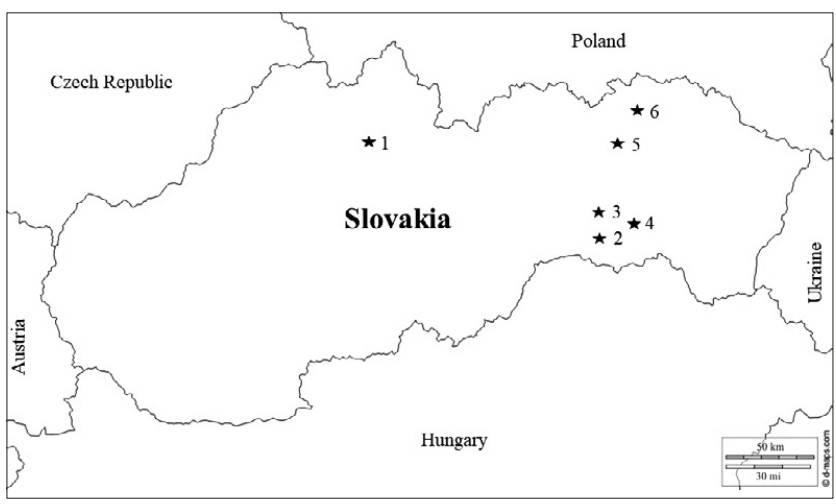

Figure 1. Geographical location of cities in Slovakia where bats were caught. 1) Ružomberok; 2) Moldava nad Bodvou; 3) Jasov; 4) Košice; 5) Sabinov; 6) Bardejov

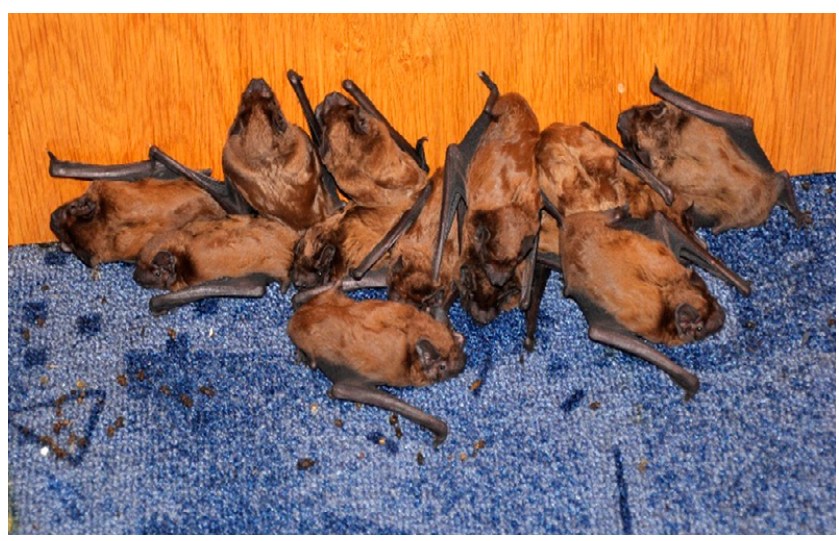

Figure 2. Common noctules (N. noctula) inside an apartment in Košice. Part of the group that invaded the building

prefabricated houses in the city of Košice were documented (Fig. 2), most of which were N. noctula and P. pipistrellus. Two common pipistrelles caught in prefabricated houses in Košice during autumn 2018 were found to be seropositive (titer 1:27).

Fluorescent antibody test of bat brain samples. In addition, 35 brains of bats (19 of P. pipistrellus and 16 of $N$. noctula) found dead inside prefabricated houses in the city Košice were analyzed. All brain samples tested negative.

Human exposure to bats. During the analyzed period between 2007 - 2019, a total of 95 cases of human exposure to bats were reported in Slovakia. Annually, bats caused $0.31 \%$ - $1.59 \%$ of human exposure cases out of the total number of confirmed incidents (Tab. 2). At the same time, between $2007-2019,12$ cases of rabies in animals were confirmed in Slovakia. The last active rabies cases were reported in 2015 (9 of foxes Vulpes vulpes, 2 of domestic dogs and 1 of the beech marten Martes foina). Cases of exposure by suspected rabid animals occurred in persons of all age groups with a peak incidence in 5 - 9-year-old children [39-51].

\section{DISCUSSION}

Bats likely form the most diverse group of mammals occurring in urban areas $[54,55]$. Humans have shared buildings with bats for thousands of years and many bat species currently have a strong ecological association with humans. Bats have
Table 2. Number of cases of human exposure to suspect rabid or rabid animals. Overview of human exposure to bats and post-exposure prophylaxis of exposed persons

\begin{tabular}{|c|c|c|c|c|c|c|}
\hline $\begin{array}{l}\stackrel{\widehat{d}}{\stackrel{N}{7}} \\
\end{array}$ & 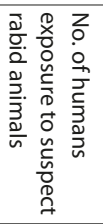 & 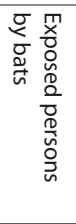 & 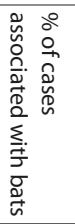 & 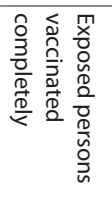 & 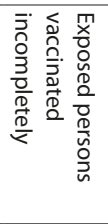 & 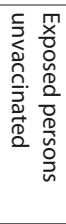 \\
\hline 2007 & 867 & 8 & 0.92 & 8 & - & - \\
\hline 2008 & 1047 & 4 & 0.38 & 4 & - & - \\
\hline 2009 & 883 & 5 & 0.57 & 5 & - & - \\
\hline 2010 & 879 & 14 & 1.59 & 12 & 1 & 1 \\
\hline 2011 & 948 & 13 & 1.37 & 12 & - & 1 \\
\hline 2012 & 963 & 10 & 1.04 & 9 & - & 1 \\
\hline 2013 & 888 & 5 & 0.56 & - & 1 & 4 \\
\hline 2014 & 1010 & 6 & 0.59 & 6 & - & - \\
\hline 2015 & 937 & 9 & 0.96 & 7 & - & 2 \\
\hline 2016 & 978 & 3 & 0.31 & 3 & - & - \\
\hline 2017 & 898 & 8 & 0.89 & 6 & 2 & - \\
\hline 2018 & 819 & 3 & 0.37 & 1 & 1 & 1 \\
\hline 2019 & 803 & 7 & 0.87 & 5 & 2 & 0 \\
\hline Total & 11,920 & 95 & 0.80 & 78 & 7 & 10 \\
\hline
\end{tabular}

Source: Annual Reports of Regional Public Health Authorities in Slovak Republic 2007-2019 [41-53].

been observed using buildings as roosting and foraging sites, temporary shelters, for reproduction and hibernation [11]. However, the coexistence between humans and bats can result in the spread of zoonotic infectious diseases [56, 57]. Since most Lyssavirus spp. are maintained by bats, direct human contact with bats is risky in terms of the possible transmission of rabies [21].

In Slovakia, lyssavirus infection of bats has been confirmed in only two cases - in 1991 and 2000 [33, 34]. According the annual reports of the State Veterinary and Food Administration of the Slovak Republic, a total of 28 samples from bats were examined between 2007 - 2019 from the whole territory of the Slovak Republic, with negative results for the rabies virus [58].

The present study confirmed the more recent circulation of bat lyssaviruses in the Slovak population of insectivorous bats. The detection of neutralizing antibodies in sera samples of two common pipistrelle bats indicates exposure to lyssaviruses. These are interesting data since no systematic active surveillance of lyssavirus circulation in bat populations has yet been introduced in the Slovak Republic. Based on the results of this study, it can be assumed that lyssaviruses are actively circulating in bats in Slovakia, and it will be necessary to investigate this problem in more detail.

The bat fauna of cities in Slovakia, as in other European countries, is relatively rich due to the high diversity of habitats and available roosts within the cities, and the developed urban areas providing many roosting opportunities for synanthropic bat species $[16,59,60]$.

According to the available literature $[13,61,62,63]$, the bats recorded in this study are considered common bat species in the urban areas of Slovakia. Bats entered the buildings through outlets of ventilation systems, unsealed openings for antenna wiring, lift shafts, leaks in older windows, as well as through cracks between individual panels. 
The common noctule (N. noctula) was the most numerous bat species in this study. It is a common species in the urban environment of both Slovakia and Central Europe [63]. N. noctula is one of the larger species of European insectivorous bats and can injure humans if handled inexpertly. The massive occurrence of this species in buildings is of interest fromthea public health perspective $[64,65]$.

In Slovakia, the common pipistrelles (P. pipistrellus) exploit shelters in buildings throughout the year, and large numbers of pipistrelle bats could also be found here during hibernation [66]. The common pipistrelle was the second most numerous bat species recorded during this study. Due to their small body size, this species can get inside buildings relatively easily. An increased frequency of $P$. pipistrellus in buildings was observed particularly in the period after the collapse of maternity colonies, and during the autumn migration,. Relatively high densities of $P$. pipistrellus during the autumn migration period, especially in the Košice area, may be related to a mass hibernaculum of pipistrelles, which is located $30 \mathrm{~km}$ west of Košice in the Erňa caves in the Slovak Karst. Up to 70,000 individuals hibernate in the Erňa caves during winter [67].

The soprano bats (P.pygmaeus), the sympatric and cryptic species with the common pipistrelle bats, were documented in only two cases. The soprano bats were incorporated into larger groups of the common pipistrelles trapped inside the flats. These two records of soprano pipistrelles incorporated into $P$. pipistrellus invasions complement the knowledge of bat invasions in Slovakia $[16,17,68]$.

The parti-coloured bats ( $V$. murinus) were recorded exclusively during the winter months, which corresponds with information obtained by other authors. All recorded individuals of $V$. murinus were males, which is probably related to the reproductive behaviour of this species, as males attract females to shelters in buildings and mate during the autumn and winter months [61].

In this study, the serotine bat (E. serotinus) are considered as the least common bat in buildings in the studied area, which is in contrast with the results of other authors $[62,69]$ However, information on the occurrence of this species in blocks of flats in Slovakia remains insufficient.

Contact or human-bat exposures are relatively common. Paterson et al. (2014), described that from a representative sample of 821 adults aged 16 years and older, 127 (15.5\%) of respondents indicated that they had previously handled a bat [70]. Potentially high risk practices were reported if respondents encountered an injured or sick bat.

Rabies is considered a disease with the highest mortality rate and all humans are vulnerable to infection, and specific anti-rabies immunoprophylaxis is the only efficient method of protection [71]. Most vaccinations are performed when animals suspected of being rabid bite patients [72]. In all, 95 human exposures to bats, that is $0.80 \%$ from a total of 11,920 human exposure cases, were reported in the Slovak Republic between 2007 - 2019.

Conflict can arise when bats roost in human dwellings and householders are affected adversely by their presence. In order to eliminate the risk of disease transmission from bats to the human population in the urban environment, it is important to apply appropriate conservation measures to avoid disturbing bats in their roosts. At the same time, it is necessary to deal effectively with human-bat conflict situations [9], although a low percentage of bat-human conflicts has been recorded with by other authors $[72,73,74]$.

\section{CONCLUSIONS}

The study confirmed the presence of lyssavirus antibodies in synanthropic bats in Slovakia, suggesting the active circulation of bat lyssaviruses in bat populations exploiting human buildings. Although the seroprevalence was found to be extremely low, the results show that any case of human exposure to bats must be treated with caution in order to protect public health. Since our knowledge about the circulation of bat lyssaviruses in Slovakia is insufficient, a systematic screening of the bat population should be carried out. All exposed people should be aware of the risk and be vaccinated to prevent possible lyssavirus transmission from bats.

\section{Acknowledgements}

This research was funded by the Ministry of Education, Science, Research and Sport of the Slovak Republic, grant number VEGA No. 1/0368/21; project implementation "Open scientific community for modern interdisciplinary research in medicine (OPENMED)“, ITMS2014+: 313011V455 supported by the Operational Programme Integrated Infrastructure, funded by the ERDF.

\section{REFERENCES}

1. Ramírez-Fráncel LA, García-Herrera LV, Losada-Prado S, et al. Bats and their vital ecosystem services: a global review. Integr Zool. 2022; 17(1): 2-23. https://doi.org/10.1111/1749-4877.12552

2. Allocati N, Petrucci AG, Di Giovanni P, et al. Bat-man disease transmission: zoonotic pathogens from wildlife reservoirs to human populations. Cell Death Discov. 2016; 2: 16048. https://doi.org/10.1038/ cddiscovery. 2016.48

3. Openshaw JJ, Hegde S, Sazzad H, et al. Bat Hunting and Bat-Human Interactions in Bangladeshi Villages: Implications for Zoonotic Disease Transmission and Bat Conservation. Transbound Emerg Dis. 2017; 64(4): 1287-1293. https://doi.org/10.1111/tbed.12505

4. Sachanowicz K, Ciechanowski M, Tryjanowski P, et al. Wintering range of Pipistrellus nathusii (Chiroptera) in Central Europe: has the species extended to the north-east using urban heat islands? Mammalia. 2019; 83(3): 260-271. https://doi.org/10.1515/mammalia-2018-0014

5. Tzortzakaki O, Papadatou E, Kati V, et al. Winners and losers in an urban bat community: a case study from southeastern Europe. Hystrix, the Italian Journal of Mammalogy. 2019; 30(2): 134-140. https://doi. org/10.4404/hystrix-00204-2019

6. Russo D, Ancillotto L. Sensitivity of bats to urbanization: a review. Mamm Biol. 2015; 80(3): 205-212. https://doi.org/10.1016/j. mambio.2014.10.003

7. Ancillotto L, Budinski I, Nardone V, et al. What is driving range expansion in a common bat? Hints from thermoregulation and habitat selection. Behav Processes. 2018; 157: 540-546. https://doi.org/10.1016/j. beproc.2018.06.002

8. Mikula P, Hromada M, Tryjanowski P. Bats and Swifts as food of the European Kestrel (Falco tinnunculus) in a small town in Slovakia. Ornis Fenn. 2013; 90(3): 178-185.

9. Stone E, Zeale MR, Newson SE. et al. Managing Conflict between Bats and Humans: The Response of Soprano Pipistrelles (Pipistrellus pygmaeus) to Exclusion from Roosts in Houses. PLoS One. 2015; 10(8): e0131825. https://doi.org/10.1371/journal.pone.0131825

10. Ruczyński I, Kalko EKV, Siemers BM. The sensory basis of roost finding in a forest bat, Nyctalus noctula. J Exp Biol. 2007; 210(20): 3607-3615. https://doi.org/10.1242/jeb.009837

11. Voigt CC, Phelps KL, Aguirre LF, et al. Bats and buildings: the conservation of synanthropic bats. In: Voigt CC, Kingston T, editors. Bats in the Anthropocene: Conservation of Bats in a Changing World. Springer International Publishing: Cham, Switzerland; 2016. pp. 427462. https://doi.org/10.1007/978-3-319-25220-9_14

12. Krištofík J, Danko Š. Cicavce Slovenska, rozšírenie, bionómia a ochrana [Mammals of Slovakia, distribution, bionomy and protection], 1st ed. Bratislava: Veda; 2012. p. 712. (in Slovak). 
13. Celuch M, Kaňuch P. Zimný výskyt netopierov v panelových blokoch na sídlisku Sekčov v Prešove [Winter occurrence of bats in prefabs houses in the Sekčov residential area in Prešov]. Vespertilio. 2002; 6: 44. (in Slovak).

14. Lehotská B. Netopiere (Chiroptera) urbanizovaného prostredia Bratislavy. [Bats of urbanised area of Bratislava city]. Acta Envir Univ Comenianae (Bratislava). 2006; 14: 61-70. (in Slovak).

15. Bačkor P. Netopiere mesta Banská Bystrica (Chiroptera) [Bats of the city of Banská Bystrica, Central Slovakia (Chiroptera)]. Lynx, new series. Prague: National Museum. 2016; 47(1): 5-15. (in Slovak). https://doi. org/10.2478/lynx-2016-0001

16. Nusová G, Fulín M, Uhrin M, et al. Spatiotemporal pattern in the autumn invasion behaviour of the common pipistrelle, Pipistrellus pipistrellus: Review with a case study. Mamm Biol. 2019; 97: 13-21. https://doi.org/10.1016/j.mambio.2019.04.005

17. Nusová G, Uhrin M, Kaňuch P. Go to the city: urban invasions of four pipistrelle bat species in eastern Slovakia. Eur J Ecol. 2019; 5(1): 23-26. https://doi.org/10.2478/eje-2019-0004

18. Brook CE, Dobson AP. Bats as 'special' reservoirs for emerging zoonotic pathogens. Trends Microbiol. 2015; 23(3): 172-180. https:// doi.org/10.1016/j.tim.2014.12.004

19. Lee SY, Chung CU, Park JS, et al. Novel viruses detected in bats in the Republic of Korea. Sci Rep. 2020; 10: 20296. https://doi.org/10.1038/ s41598-020-77307-4

20. Zhou H, Ji J, Chen X, et al. Identification of novel bat coronaviruses sheds light on the evolutionary origins of SARS-CoV-2 and related viruses. Cell. 2021; 184: 4380-4391. https://doi.org/10.1016/j.cell.2021.06.008

21. Fooks AR, Cliquet F, Finke S, et al. Rabies. Nat Rev Dis Primers. 2017; 3: 17091. https://doi.org/10.1038/nrdp.2017.91

22. Banyard AC, Evans JS, Luo TR, et al. Lyssaviruses and bats: emergence and zoonotic threat. Viruses. 2014; 6(8): 2974-2990. https://doi. org/10.3390/v6082974

23. ICTV. Genus: Lyssavirus - Rhabdoviridae - Mononegavirales International Committee on Taxonomy of Viruses (ICTV). 2020. Available online: https://talk.ictvonline.org/ictv-reports/ictv_online_report/ negative-sense-rna-viruses/mononegavirales/w/rhabdoviridae/795/ genus-lyssavirus (access: 2021.5.28).

24. Calvelage S, Tammiranta N, Nokireki T. et al. Genetic and Antigenetic Characterization of the Novel Kotalahti Bat Lyssavirus (KBLV). Viruses. 2021; 13(1): 69. https://doi.org/10.3390/v13010069

25. Mélade J, McCulloch S, Ramasindrazana B. et al. Serological Evidence of Lyssaviruses among Bats on Southwestern Indian Ocean Islands. PLoS One. 2016; 11(8): e0160553. https://doi.org/10.1371/journal.pone.0160553

26. McColl KA, Tordo N, Aguilar Setién AA. Bat lyssavirus infections. Rev Sci Tech Off Int Epiz. 2000; 19(1): 177-196. http://dx.doi.org/10.20506/ rst.19.1.1221

27. Kuzmin IV, Rupprecht CE. Bat rabies; In Jackson AC, Wunner, WH, editors. Rabies. 2nd ed.; Academic Press: London, Great Britain. 2007; pp 259-307. https://doi.org/10.1016/B978-012369366-2/50008-7

28. Shipley R, Wright E, Selden D, et al. Bats and Viruses: Emergence of Novel Lyssaviruses and Association of Bats with Viral Zoonoses in the EU. Trop Med Infect Dis. 2019; 4(1): 31. https://doi.org/10.3390/ tropicalmed4010031

29. Coxon C, McElhinney L, Pacey A, et al. Preliminary Outbreak Assessment: Rabies in a Cat in Italy. 2020. Available online: https://www. who-rabies-bulletin.org/site-page/classification (access: 2020.11.10).

30. Regnault B, Evrard B, Plu I, et al. First case of lethal encephalitis in Western Europe due to European bat lyssavirus type 1. Clin Infect Dis. 2021; ciab443. https://doi.org/10.1093/cid/ciab443

31. Vega S, Lorenzo-Rebenaque L, Marin C, et al. Tackling the Threat of Rabies Reintroduction in Europe. Front Vet Sci. 2021; 7: 613712. https:// doi.org/10.3389/fvets.2020.613712

32. Schatz J, Fooks AR, McElhinney L, et al. Bat rabies surveillance in Europe. Zoonoses Public Health. 2013; 60(1): 22-34. https://doi. org/10.1111/zph.12002

33. Ondrejková A, Franka R, Ondrejka R, et al. Identification of a Lyssavirus isolate from a bat (Eptesicus serotinus). Bull Vet Inst Pulawy. 2004; 48(1): 11-13.

34. Ondrejková A, Švrček Š, Ondrejka R, et al. Historical analysis of epizootiological situation of rabies on the territory of the Slovak Republic. Acta Virol. 2020; 64(2): 216-225. https://doi.org/10.4149/ av_2020_211

35. Couper D. Bats. In: Mullineaux E, Keeble E, editors. BSAVA Manual of Wildlife Casualties, 2nd ed. Gloucester: British Small Animal Veterinary Association; 2016. p. 175-191.

36. Dietz C, von Helversen O. Illustrated identification key to the bats of Europe. Electronic Publication. Version 1.0 released 15. 12. 2004.
Tuebingen \& Erlangen, Germany, 2004. Available online: https:// www.chiroptera.se/documents/Illustrated_Key_to_European_Bats. pdf (access: 2021.5.28).

37. Smith JS, Yager PA, Baer GM. A rapid reproducible test for determining rabies neutralizing antibody. Bull World Health Organ. 1973; 48(5): 535-541. PMID: 4544144.

38. Zalan E, Wilson C, Pukitis D. A microtest for the quantitation of rabies virus neutralizing antibodies. J Biol Stand. 1979; 7(3): 213-220. https:// doi.org/10.1016/s0092-1157(79)80024-4

39. Reed LJ, Muench H. A simple method of estimating fifty per cent endpoints. Am J Epidemiol. 1938; 27(3): 493-497. https://doi. org/10.1093/oxfordjournals.aje.a118408

40. Dean DJ, Abelseth MK. Laboratory techniques in rabies: The fluorescent antibody test. Monogr Ser World Health Organ. 1973; 23: 73-84. PMID: 42195.

41. RPHA. Annual report of Regional Public Health Authorities in Slovak Republic in the year 2007. Available online: https://www.uvzsr.sk/docs/ vs/vyrocna_sprava_SR_07.pdf (access: 2021.5.28). (in Slovak).

42. RPHA. Annual report of Regional Public Health Authorities in Slovak Republic in the year 2008. Available online: https://www.uvzsr.sk/ docs/vs/vyrocna_sprava_SR_08.pdf (access: 2021.5.28). (in Slovak).

43. RPHA. Annual report of Regional Public Health Authorities in Slovak Republic in the year 2009. Available online: https://www.uvzsr.sk/docs/ vs/vyrocna_sprava_SR_09.pdf (access: 2021.5.28). (in Slovak).

44. RPHA. Annual report of Regional Public Health Authorities in Slovak Republic in the year 2010. Available online: https://www.uvzsr.sk/docs/ vs/vyrocna_sprava_SR_10.pdf (access: 2021.5.28). (in Slovak).

45. RPHA. Annual report of Regional Public Health Authorities in Slovak Republic in the year 2011. Available online: https://www.uvzsr.sk/docs/ vs/vyrocna_sprava_SR_11.pdf (access: 2021.5.28). (in Slovak).

46. RPHA. Annual report of Regional Public Health Authorities in Slovak Republic in the year 2012. Available online: https://www.uvzsr.sk/docs/ vs/vyrocna_sprava_SR_12.pdf (access: 2021.5.28). (in Slovak).

47. RPHA. Annual report of Regional Public Health Authorities in Slovak Republic in the year 2013. Available online: https:/www.uvzsr.sk/ docs/vs/vyrocna_sprava_SR_2013.pdf(access: 2021.5.28). (in Slovak).

48. RPHA. Annual report of Regional Public Health Authorities in Slovak Republic in the year 2014. Available online: https://www.uvzsr.sk/ docs/vs/vyrocna_sprava_SR_2014.pdf (access: 2021.5.28). (in Slovak)

49. RPHA. Annual report of Regional Public Health Authorities in Slovak Republic in the year 2015. Available online: https://www.uvzsr.sk/ docs/vs/vyrocna_sprava_SR_2015.pdf(access: 2021.5.28). (in Slovak).

50. RPHA. Annual report of Regional Public Health Authorities in Slovak Republic in the year 2016. Available online: https://www.uvzsr.sk/ docs/vs/vyrocna_sprava_SR_2016.pdf (access: 2021.5.28). (in Slovak).

51. RPHA. Annual report of Regional Public Health Authorities in Slovak Republic in the year 2017. Available online: https:/www.uvzsr.sk/ docs/vs/vyrocna_sprava_SR_2017.pdf (access: 2021.5.28). (in Slovak).

52. RPHA. Annual report of Regional Public Health Authorities in Slovak Republic in the year 2018. Available online: https://www.uvzsr.sk/ docs/vs/vyrocna_sprava_SR_2018.pdf(access: 2021.5.28). (in Slovak).

53. RPHA. Annual report of Regional Public Health Authorities in Slovak Republic in the year 2019. Available online: https://www.uvzsr.sk/ docs/vs/vyrocna_sprava_SR_2019.pdf (access: 2021.5.28). (in Slovak).

54. van der Ree R, McCarthy MA. Inferring persistence of indigenous mammals in response to urbanisation. Anim Conserv. 2005; 8(3): 309-319. https://doi.org/10.1017/S1367943005002258

55. Jung K, Kalko EKV. Adaptability and vulnerability of high flying Neotropical aerial insectivorous bats to urbanization. Divers Distrib. 2011; 17(2): 262-274. https://doi.org/10.1111/j.1472-4642.2010.00738.x

56. Hayman DT, Bowen RA, Cryan PM, et al. Ecology of zoonotic infectious diseases in bats: current knowledge and future directions. Zoonoses Public Health. 2013; 60(1): 2-21. https://doi.org/10.1111/zph.12000

57. Zemanová S, Korytár L', BenkőZ, et al. Ecological factors of transmission, persistence and circulation of pathogens in bat populations. Folia Vet. 2019; 63(1): 32-40. https://doi.org/10.2478/fv-2019-0005

58. SVFA SR. Výročné správy a verejné odpočty za roky 2007-2019 [Annual reports of the State Veterinary and Food Administration of the Slovak Republic in years 2007-2019] Available online: https://www.svps.sk/ zakladne_info/oznamenia.asp (access: 2021.5.28). (in Slovak).

59. Kelcey JG. Vertebrates and Invertebrates of European Cities: Selected Non-Avian Fauna. Springer: New York, USA, 2015. p. 700. https://doi. org/10.1007/978-1-4939-1698-6

60. Tóth-Ronkay M, Bajor Z, Bárány A, et al. Budapest In: Kelcey JG, editor. Vertebrates and Invertebrates of European Cities: Selected Non-Avian Fauna. New York: Springer; 2015. p. 27-73. https://doi. org/10.1007/978-1-4939-1698-6 
61. Matis Š, Dittel L. Jesenné pozorovania Vespertilio murinus v niektorých mestách na Slovensku [Autumnal observations of Vespertilio murinus in some Slovak towns]. Vespertilio. 1997; 2: 141-142. (in Slovak).

62. Lehotská B, Lehotský R. Skúsenosti z ochrany zimnej kolónie raniaka hrdzavého (Nyctalus noctula) v panelovom dome na bratislavskom sídlisku Dlhé Diely [Experiences of protecting the winter colony of Nyctalus noctula in a prefab at the Bratislava housing estate Dlhé Diely (Slovakia)]. Vespertilio; 2000; 4: 105-110. (in Slovak).

63. Celuch M, Danko Š, Kaňuch P. On urbanisation of Nyctalus noctula and Pipistrellus pygmaeus in Slovakia. Vespertilio. 2006; 9-10: 219-221.

64. Straková P, Dufkova L, Širmarová J, et al. Novel hantavirus identified in European bat species Nyctalus noctula. Infect Genet Evol. 2017; 48: 127-130. https://doi.org/10.1016/j.meegid.2016.12.025

65. Orłowska A, Smreczak M, Freuling CM, et al. Serological Survey of Lyssaviruses in Polish Bats in the Frame of Passive Rabies Surveillance Using an Enzyme-Linked Immunosorbent Assay. Viruses. 2020; 12(3): 271. https://doi.org/10.3390/v12030271

66. Danko Š, Kaňuch P, Uhrin M, et al. Večernica hvízdavá - Pipistrellus pipistrellus [The common pipistrelle - Pipistrellus pipistrellus] In: Krištofík J, Danko Š. Cicavce Slovenska, rozšírenie, bionómia a ochrana [Mammals of Slovakia, distribution, bionomy and protection], 1st ed. Bratislava: Veda; 2012. p. 378-383. (in Slovak).

67. Matis Š, Uhrin M, Pjenčák P. Zimovanie netopierov v jaskyni Erňa. [Hibernation of bats in Erňa cave] Vespertilio. 2002; 26: 235-236. (in Slovak).

68. Kaňuch P, Fornůsková A, Bartonička T, et al. Do two cryptic pipistrelle bat species differ in their autumn and winter roosting strategies within the range of sympatry? Folia Zool. 2010; 59(2): 102-107. https://oi. org/10.25225/fozo.v59.i2.a4.2010

69. Danko Š, Lehotská B, Lehotský R, et al. Večernica pozdná - Eptesicus serotinus [The serotine bat - Eptesicus serotinus] In: Krištofík J, Danko Š. Cicavce Slovenska, rozšírenie, bionómia a ochrana [Mammals of Slovakia, distribution, bionomy and protection], 1st ed. Bratislava: Veda; 2012. p. 353-360. (in Slovak).

70. Paterson BJ, Butler MT, Eastwood K, et al. Cross sectional survey of human-bat interaction in Australia: public health implications. BMC Public Health. 2014; 14: 58. https://doi.org/10.1186/1471-2458-14-58

71. Tomasiewicz K, Fota-Markowska H, Krzowska-Firych J, et al. Postexposure anti-rabies prophylaxis in Lublin province (Eastern Poland) in 2004-2005. Ann Agric Environ Med. 2006; 13(2): 337-340. PMID: 17196010 .

72. Lyczak A, Tomasiewicz K, Krawczuk G, et al. Epizootic situation and risk of rabies exposure in Polish population in 2000, with special attention to Lublin province. Ann Agric Environ Med. 2001; 8(2): 131-135. PMID: 11748869.

73. Krzowska-Firych J, Tomasiewicz K, Sukhadia T, et al. Post-exposure anti-rabies prophylaxis in humans exposed to animals in Lublin province (Eastern Poland) in 2006-2011. Ann Agric Environ Med. 2012; 19(2): 275-278. PMID: 22742801.

74. Krzowska-Firych J, Tomasiewicz K, Kozøowska A. Post-exposure rabies prophylaxis in humans exposed to animals in Lublin province (Eastern Poland) in 2012-2015 - A retrospective study. Hum Vaccin Immunother. 2017; 13(6): 1346-1351. https://doi.org/10.1080/216455 15.2017.1285474 